\title{
Middle Years Teachers' Critical Literacy Practices as Cornerstones of Their Culturally Relevant Pedagogies
}

\author{
Anne Murray-Orr and Jennifer Mitton
}

\begin{abstract}
Critical literacy is widely accepted as an important element of culturally relevant pedagogy. In this article, we detail results of a study into how six teachers in rural Eastern Canada purposefully incorporated critical literacy into teaching and learning activities in their classrooms from a culturally relevant pedagogical stance. Findings highlight teachers' intentional planning that embeds critical literacy, critical literacy in the wider community, and use of multimodal practices in teaching for critical literacy. The critical literacy practices of these teachers reflect their thinking about knowledge and knowledge construction as one key aspect of their culturally relevant pedagogy.
\end{abstract}

\section{Background}

Operationalizing culturally relevant pedagogy (CRP) in the classroom requires more than a particular attitude, although attitude is vital. "Culturally relevant teachers envision their students as being filled with possibilities. They imagine that somewhere in the classroom is the next Nobel laureate..." (Ladson-Billings, 2008, p. 165). Along with this commitment to seeing all students as filled with possibilities, the ability to plan, teach, and assess in ways that support this commitment are needed. Critical literacy is widely accepted as an important part of CRP. Morrison et al. (2008) used Ladson-Billings' (1995) theoretical framework to organize a synthesis of 45 research studies on how teachers enact CRP in their classrooms, finding that many teachers employed critical literacy instruction as part of a practice that "emphasizes academic success for all students..., assists students in the formation of a positive cultural identity... and guides students in developing a critical consciousness... [the three] central tenets" (Morrison et al., 2008, p. 434) of CRP Ladson-Billings outlined.

What does critical literacy instruction look like, however, in the middle years classrooms of teachers who are committed to CRP, particularly those who are experienced and knowledgeable about what it means to enact critical literacy practices as part of their culturally relevant teaching? This was one of the questions of a research study undertaken in rural Eastern Canada by the authors of this paper over nearly two school years, from September 2016 to March 2018, funded by the Nova Scotia Department of Education and Early Childhood Development through the Inter-University Research Network.

Defining the elements of critical literacy practices is a first step toward answering this question. Lewison et al. (2002) completed an extensive review of the literature on critical literacy and found four interwoven dimensions of teacher practice which informed their research: seeing common events or ideas from new perspectives; examining multiple and contradictory viewpoints; working to understand sociopolitical 
systems that underpin existing structures; and activism for social change. Morrison et al. (2008) described "subtle variations" (p. 441) in how critical literacy was employed in classrooms across empirical studies they investigated. Similar to Lewison and colleagues, they found four common approaches in their analysis: "selecting texts with critical perspectives...providing critical thinking prompts before reading a text...allowing students to discuss controversial topics...and asking students to take a critical/political view of texts" (p. 441). With the aim of contributing to the documented evidence of how teachers practice CRP in their classrooms, and how critical literacy is an integral part of CRP, we employed the Lewison et al. framework to identify how six teachers purposefully incorporated critical literacy into planning and enacting the teaching and learning activities of their classrooms from a CRP stance.

Evident in both these critical literacy frameworks is a commitment to high academic expectations on the part of teachers. Ladson-Billings (2014), in a discussion of a "remix" (p. 74) of her theory of culturally relevant pedagogy, affirmed that expectations of academic achievement are central to CRP, and are closely linked with cultural revitalization and sociopolitical consciousness. She described the "newer concept of culturally sustaining pedagogy [as] ...built on the same foundational notion" (p. 77) of belief in the assets of learners, in a statement of the "secret behind culturally relevant pedagogy: the ability to link principles of learning with deep understanding of (and appreciation for) culture" (p. 77). Further, Ladson-Billings reminds us that a focus on engaging students as active learners who will thrive when given the opportunity to employ their sociopolitical consciousness leads to students who "take both responsibility for and deep interest in their education" (p. 77).

\section{Critical Literacy as Foundational to Culturally Relevant Pedagogy}

A number of scholars have developed principles of culturally relevant pedagogy over the past two and a half decades (Gay, 2002; Ladson-Billings, 1995; Villegas \& Lucas, 2002). Embedded in most CRP models is the notion that critical literacy is a cornerstone of culturally relevant pedagogy. In fact, culturally relevant teaching necessarily includes a critical perspective, according to Norris and colleagues (2012). In an example of the integral relationship between CRP and critical literacy, Lopez (2011) conducted a study of the experiences of a Grade 12 English teacher of a culturally diverse group of students in Toronto, Canada, who purposefully redesigned her Writer's Craft course "to build cross-cultural understandings and increase student engagement through culturally relevant pedagogy and critical literacy" (p. 76). Lopez stated that, "critical literacy gives practical expression...to the theory of culturally relevant pedagogy...it is about having a critical voice that is heard, felt and understood" (p. 78). In literacy education, critical literacy is a common term among scholars, researchers, and teachers (Lee, 2011). Clarifying the term "critical" tends to generate much debate, as "confusion remains regarding the difference between 'critical' from the Enlightenment period, which focused on critical thinking and reasoning, and 'critical' from Marx as an analysis of power" (Vasquez et al., 2019, p. 300). In turn, attempts to define the term critical influence efforts to clarify the concept of critical literacy (Vasquez et al., 2019). Literacy, in this sense, is informed by acts of cooperation and collaboration, as "how teachers negotiate critical literacy practices depends very much on the affordance of their place and the students 
Middle Years Teachers' Critical Literacy Practices as Cornerstones of Their Culturally Relevant Pedagogies

in the room...critical literacies can be pleasurable and transformational as well as pedagogical and transgressive" (Vasquez et al., 2019, p. 300). Critical literacy plays a foundational role in CRP as it heightens awareness about how knowledge is socially constructed and the need to assess texts (in all their forms) to inform decisions in contextually responsive ways (Lee, 2011).

\section{Support of Students' Critical Literacy Needs to Be Deliberately Planned}

Alim and colleagues (2017) build upon the CRP theorizing of the past two decades with their work on culturally sustaining pedagogy (CSP), reminding us that CSP "cannot and should not sustain only the aspects of students' lives that are safe or easily addressable in schooling spaces, but that they should...prepare youth to recognize, accept, and challenge social injustices" (p. 36). Finding ways to fulfill this goal calls for teachers to plan with care and thoughtfulness. Alim et al. (2020) suggest one example in their discussion of Hip Hop Pedagogies, inviting a critical focus on youth-generated texts as they note, "studies rarely look critically at how youth might reify existing hegemonic discourses about, as examples, gender, race, sexuality and citizenship" (p. 269). This example highlights one way to support youth to apply critical literacy practices to texts produced by non-dominant systems.

Souto-Manning (2009) found that first grade students eagerly engaged in critical thinking and cultural awareness, displaying insightfulness in discussing controversial topics. These discussions and learning "did not occur, however, without a deliberate starting point" (p. 52). This author chose children's books that represented social issues to engender conversations. Beyond selecting and introducing these texts, she deliberately facilitated opportunities for "critical literacy events to further the conversation" (p. 52). Souto-Manning situated her study in Larson and Marsh's (2005) definition of critical literacy, with an emphasis on challenging power relationships and seeing "texts as ideological constructions, informed by authorial intent and issues relating to power" (p. 53). Similarly, Borsheim and colleagues (2014) developed a framework called critical literature pedagogy, which includes "reading against a text...to examine how it is embedded in and shaped by ideologies" (p. 124), using non-canonical texts to emphasize the silencing of marginalized voices in the texts typically taught in high school English courses.

Morrison et al. (2008) found that teachers employed a "broad range of actions" (p. 441) to help students hone their critical literacy, such as critical analyses of texts, including course textbooks. These actions were not limited to textbooks, also involving alternative texts, classroom discussion, and writing assignments which "addressed critical questions posed by teachers and their classmates" (p. 441). Teachers incorporating these varied approaches spent time thoughtfully researching and planning in preparation for their lessons.

\section{Teachers' Understanding of CRP Must Include a Critical Literacy Perspective}

Hyland (2005) explored what happened when white teachers of black students saw themselves as good teachers, but employed some, rather than all, the elements of CRP. For example, one teacher worked to make her classroom welcoming for students and had positive relationships with families, but did nothing 
to help her students look critically at the world. Hyland states that this approach resulted in unintentional racism and suggests that these teachers' partial understanding of CRP may be behind this embedded racism. Hyland calls for "critical teacher educators and researchers...to continue to find ways to work with small groups of teachers...to begin to counter the racism that is embedded in schools...and even within their own definitions of successful teaching" (p. 458). Hyland's call reflects Ladson-Billings' (2014) affirmation that cultural competence must be integrated with use of principles of learning that draw upon learners' assets and engage their sociopolitical consciousness. As noted in previous sections, these principles include provision of opportunities to engage in critical literacy practices.

Sleeter (2012) described how CRP has been marginalized by neoliberal agendas in the United States and notes that often an overly simplistic view of CRP may be enacted in schools, when CRP is "understood as cultural celebration" (p. 568). Lopez (2011) discussed challenges at the local level of the school and district, noting that, "culturally relevant pedagogy and critical literacy within a climate of standardization is challenging and complex. Some teachers...hold fast to the "canons" and see efforts at... [CRP] practices as "watering down" the curriculum" (p. 90). Flores (2007) documented the struggles of four new teachers to maintain a social justice practice that included CRP. Without the inclusion of a critical literacy perspective, these issues will continue to plague the education system.

\section{Theoretical Framework: Critical Literacy as a Cornerstone of CRP}

Ladson-Billings (1995) theorized three key areas of CRP from her research with teachers: how teachers see themselves and their students and students' families/communities; how teachers construct their relationships with students, families, and communities; and how teachers think about knowledge and knowledge construction. More recently, Ladson-Billings (2014) upheld the significance of these three areas while lending her support for the more recent turn to culturally sustaining pedagogy. In the study on which this article is based, there was ample evidence of teachers' commitment to a pedagogy that included all three areas. It is the third area, conceptions of knowledge, that is central in this paper. Ladson-Billings (1995) asserts that, "knowledge must be viewed critically" (p. 481). Therefore, we focus on critical literacy as a vital component of CRP, using Lewison and colleagues' (2002) distillation of four dimensions of critical literacy to better understand how the teachers in this study acted on their conceptions of knowledge and knowledge construction.

Ladson-Billings (1992) explained that, "culturally relevant teaching serves to empower students to the point where they will be able to examine critically educational content and process, and ask what its role is in creating a truly democratic and multicultural society" (p. 106). The connection between critical literacy and CRP is strong, as critical analysis of multiple texts invites examination of unequal power relationships and disrupting of the commonplace.

CRP is considered to have "unique roots and central emphases, [and to] share a commitment to promoting social and educational equity and justice" (Dover, 2009, p. 514) with other related philosophies. Dover (2009) created a model in which culturally relevant education is one of five distinct 
Middle Years Teachers' Critical Literacy Practices as Cornerstones of Their Culturally Relevant Pedagogies

traditions that are foundational to teaching for social justice. She notes that teaching practices that promote critical thinking habits are essential to "teaching for social justice [that] focuses on instruction about educational and societal oppression, equity and activism" (p. 514). Related to Dover, Brown-Jeffy and Cooper (2011) explored the "evolution of CRP among [the works of] some of the leading scholars" (p. 66) to develop their CRP conceptual framework. The CRP framework developed by Brown-Jeffy and Cooper (2011) is made up of five sets of concepts: identity and achievement; equity and excellence; developmental appropriateness; teaching the whole child; and student-teacher relationships. While they do not include critical literacy in their model explicitly, their description of each of the five strands, and of identity and achievement in particular, suggests that critical literacy is imperative to a CRP practice.

Also informing this study are the six strands Villegas and Lucas (2002) conceptualized as a curriculum for preparing culturally responsive teachers. Villegas and Lucas note that CRP is "not simply a matter of applying instructional techniques" (p. 27). Rather, "culturally responsive teachers have a high degree of sociocultural consciousness" (p. 27), enabling them to "cross the sociocultural boundaries that separate too many of them from their students" (p. 22). While the findings of this paper focus on the critical literacy practices of the teachers, it was a purposefulness infused with sociocultural consciousness that informed their planning and teaching. We note the interplay between their beliefs and pedagogy as particularly key to their commitment to crafting CRP in which their students could academically flourish.

\section{Methodology}

The main purpose of the qualitative research project this paper draws upon was to find common themes or trends across multiple observations in middle years classrooms, and across interviews with teachers and students, to determine the kinds of literacy practices that enable improved literacy acquisition and stronger achievement of learning outcomes for students across subject areas. We approached administrators of the two schools in which we conducted this study to work with us to identify teachers who demonstrated commitment and success in terms of literacy achievement of, and relationships with, students from racialized populations and those experiencing poverty.

\section{Schools and Teacher Participants}

The first school, New Learning Academy (pseudonym), where data was collected in 2016-2017, was a P-8 school of approximately 550 students in a community with a significant population of African Nova Scotians and students who experience poverty. Four teachers, identified by the principal, took part in the research in that school. Here are their pseudonyms and a brief description of their teaching responsibilities:

- $\quad$ Jackie Purcell: Grade 5 all subjects; 32 years teaching experience (TE)

- $\quad$ Paige Raymond: Grades 5 and 6: ELA and Social Studies; 26 years TE

- $\quad$ Foley Mackenzie: Grades 7 and 8 Science; 8 years TE

- $\quad$ Gina Sears: Grade 8 Social Studies and Art; 15 years TE 
The second school, where data was collected in 2017-2018, was Highlands Middle School (pseudonym), a school of approximately 350 students with a small population of African Nova Scotian students and a significant population of students who experience poverty. Two teachers took part in the research at that school. They are:

- $\quad$ Marla Griffin: Combined Grade 5/6 all subjects; 4 years TE

- $\quad$ Jeremy Spencer: Grade 8 ELA, Social Studies, Health, Physical Education; 20 years TE

\section{Methods of Data Collection}

The following data collection methods were used in the study:

\section{Observations}

A member of our research team conducted observations in the classrooms of the teachers identified in each school once a week as consistently possible. To increase reliability, one coresearcher led data collection at each school. Jennifer led the data collection at the first school, New Learning Academy, and had three research assistants accompany her at that school. Anne led the data collection at the second school, Highlands Middle School, and had one research assistant accompany her. Field notes were taken during observations, to describe the literacy practices teachers use to promote learning. In total we conducted 54 observations in across all four classrooms in NLA from late-September 2016 to May 2017, and 30 observations across the two classrooms in HMS from October 2017 to February 2018.

\section{Teacher Interviews}

The teacher participants at both schools were interviewed twice, at the beginning and end of the data collection process, to learn more about how they plan for, teach, and assess lessons that incorporate literacy practices to promote the learning of students from racialized populations and those experiencing poverty. These interviews were audio-recorded, and field notes were taken.

\section{Student Focus Groups}

Focus groups were held with students in classrooms of each of the teacher participants at NLA twice during the study. Focus groups were held with students in classrooms of teacher participants at HMS once during the study. The focus groups were audio-recorded, and field notes were taken.

\section{Ethics Protocols}

We were granted approval to conduct the study from the University Research Ethics Board. We then applied for and were granted permission from each regional education centre involved in our study, as well as Mi'kmaq Ethics Watch. In order to respect confidentiality in the reports and documents resulting from this study, pseudonyms are used for students, staff, and schools. 
Middle Years Teachers' Critical Literacy Practices as Cornerstones of Their Culturally Relevant Pedagogies

\section{Data Analysis Procedures}

This study generated a data set from which we determined five themes arising from what teacher and student participants told us about the culturally relevant and effective approaches to developing literacy skills in their classrooms, and what we observed to be successful practices during classroom observations. The process of data analysis involved inductively analyzing as we read and reread the data (Creswell, 2007; Merriam \& Tisdell, 2016). A research assistant was hired to organize the data for analysis during the summer months of 2017 and 2018. We noted themes or trends emerging across the data, highlighting teaching approaches and learning activities that supported literacy development of students from racialized populations and those experiencing poverty. The four dimensions of critical literacy, as defined by Lewison et al. (2002), informed our analysis in concert with the principles of culturally relevant pedagogy defined by Brown-Jeffy and Cooper (2011) and the CRP theory of Ladson-Billings (1995).

\section{Findings}

Critical literacy practices were present in the practices of all six teachers in this study, and reflected their commitment to CRP throughout the time spent in their classrooms. There are three main subthemes related to teachers' planning and teaching that included critical literacy practices: intentional planning that embeds critical literacy; critical literacy in the wider community; and use of multimodal practices in teaching for critical literacy.

\section{Intentional Planning of Critical Literacy Opportunities}

As Souto-Manning (2009) noted, intentional planning is necessary for fostering critical literacy among students. The practices of teachers in this study illustrated their awareness that critical literacy develops in classrooms over time and must be consciously integrated. For example, in Jackie's Grade 5 class there was an ongoing emphasis on gender equity integrated throughout various lessons and activities. During a social studies lesson about the Middle Ages, Jackie and her students were reading a section of the textbook when Jackie took a moment to pause and consider the gendered nature of the scene being described.

Brianna read aloud that girls during the Middle Ages tended to work with their mothers at home. In response to this sentence, Jackie intervened quickly, saying, "Just wait a minute!" She asked the whole class if this (girls only being allowed to work at home with their mothers) happened today. The students resoundingly said, "No!", and Jackie said, "Right, girls can do anything."(Observation Notes, April 28, 2017)

Gender equity was a theme that Jackie consciously integrated into the curriculum in ways that felt seamless and authentic. While this example appears nonchalant and effortless, this inclusion changed the tone of the lesson and engaged students critically with their textbooks. It was part of a continuing plan Jackie carefully included across subject areas to provide students with practice in reading against the text (Borsheim-Black et al., 2014), interrogating multiple perspectives (Lewison et al., 2002) and challenging systems of oppression (Dover, 2009). 
Jeremy's approach to the Grade 8 social studies curriculum focused on Canada's marginalized populations whose voices are not featured in the dominant narrative of Canada's past. The following example is from a social studies lesson about unjust Canadian immigration policies that targeted Chinese Canadians in particular, in which Jeremy wove back and forth between classroom discussion and students reading and responding to questions in his Google classroom. The questions that students answered during this lesson correspond with two dimensions of critical literacy defined by Lewison and colleagues (2002), displacing the commonplace and interrogating multiple perspectives. During the lesson, Jeremy had students engage with multiple primary source texts he researched in his course planning, which described the impacts of Canadian policies on Chinese Canadian populations during the early 20th century (The Empire Settlement Act of 1922; The Chinese Immigration Act of 1923; The Railway Agreement of 1925) and answer the following questions:

1. We have looked at Canada's policy for Chinese Immigrants in 1923. Do you think that this was a fair policy? Why or why not?

2. How was the Empire Settlement Act different from the Chinese Immigration Act?

3. How did the Railway Agreement of 1925 further discriminate against Chinese immigrants?

Jeremy challenged his students to consider how the Canadian government treated Chinese immigrants in the 1920s in relation to how they treated European immigrants at that time. Partway through this lesson, Jeremy asked his students to pause and ponder how Chinese Canadians and Chinese immigrants might feel as these primary source documents affected their daily lives during the 1920s.

Jeremy asks students how would it feel if we were made to walk around with photo IDs all the time. Students replied that it would be sad or scary. He then points them to the date of the Act, July 1st, [now celebrated as] Canada Day. Students reply with comments like, "whoa" and "that's sad."(Observation Notes, January 18, 2018)

In this teaching moment, Jeremy challenged the commonly held belief that Canada has always been a welcoming and multicultural nation. Jeremy asked his students to consider multiple perspectives as they were interrogating primary source documents, providing a powerful example of planning to foster critical literacy among his Grade 8 students.

\section{Critical Literacy in the Community}

Critical literacy includes moving from the confines of the classroom into the wider community, and we observed how teachers in this study engaged students with important issues pertinent to their own communities. At least two of the four dimensions of critical literacy articulated by Lewison et al. (2002) were visible in the classrooms of the teachers in this study, seeing common events or ideas from new perspectives and working to understand sociopolitical systems that underlie existing structures. There were examples of teachers engaging students in learning how to access various community services, taking part in activities to understand how the voting process works, and reconsidering local heritage events. 
Middle Years Teachers' Critical Literacy Practices as Cornerstones of Their Culturally Relevant Pedagogies

Gina's approach to Grade 8 social studies demonstrated her commitment to critical literacy in the community. Many of her lessons involved authentic connections with events happening in the community. For example, when the town was conducting municipal elections, Gina used this as an opportunity to teach her students about the civic electoral system. In planning for this activity, Gina organized students according to their electoral districts, asked them to bring in promotional flyers from the candidates, and discussed the platforms of each candidate with the class, with the activity culminating in a class vote on election day.

Gina helped build her students' critical literacy skills through lessons on how to actively engage in the community and have a say in municipal affairs. Gina's intention was for her students to become more engaged with their community. After the actual election had taken place, Gina noted:

Yeah, we had a good talk about that on Monday when we looked at the results and then I asked, how many of you on the weekend checked out who won? A large percentage did because they wanted to know if their vote was similar to what the town had said and they were very passionate about the mayor...I think those are the kinds of things that we need to be literate in: how to vote, and how to...how do I access different services. ...We've done a bunch of work on who to call if I'm not happy with the snow removal; if my streetlight is out; if I don't have a family doctor. (Interview, October 2, 2016)

Gina's approach to critical literacy made clear to students that they can have a voice in the decisions made in their town, both through larger events like elections and in the day-to-day aspects of community life in their local context. This was part of her goal to have students learn to advocate for themselves within and beyond their communities, which is aligned with the community-oriented focus of Ladson-Billings' (1995) three pillars of CRP.

Marla's approach to critical community literacy involved engaging her students in local events such as the launch of African Heritage Month, which occurred in early February 2018. Marla, who leads an African drumming group in the community, was invited to perform at the event. To extend this event to involve her Grade 5/6 class, Marla entered her students into a poetry contest, and four poems were selected to be read at the launch. Marla explained why she brings her students to events such as this.

It's great for some of these kids to be able to...attend events like this, because a lot of them come from socioeconomic backgrounds where they aren't able to play on expensive sports teams and do after school extracurricular activities. She said events like this make students feel as if they are a part of something. (Observation Notes, January 25, 2018)

Marla's awareness of her students' need to feel as if they are anchored in their community is evident. By providing her students with opportunities to be involved, she is paving the way for them to see these events in their town from new perspectives, honing their critical community literacy skills. Marla stated that she is "a firm believer that it takes a village...to educate a child" Taking her students out in to the community, and being active herself in the community, "is another perspective that I'm bringing to the classroom because it's not just me that's making all of these kids successful" (Interview, February 12, 2018). Marla's beliefs reflect her commitment to CRP, and in particular to Ladson-Billings' (1995) focus on teachers constructing relationships with students, families, and communities. 


\section{Multimodal Practices in Teaching for Critical Literacy}

This section examines how teachers incorporated varied text and modes of expression as they taught for critical literacy. As Lopez (2011) noted, clinging to the canonical texts is no longer appropriate (if it ever was). New and relevant modes of consuming information and expressing one's ideas and opinions are part of a critical literacy approach. Within the examples that follow, there is an emphasis on access to ensure that all students can participate in an activity. Students also learned how to critically engage with media sources. We draw on two examples here. In the first, we highlight Jeremy's Grade 8 class, who were engaged in creating podcasts about a diverse variety of books that small groups had read in book club. During a classroom observation by one of the researchers,

Two students...explained they are using GarageBand to make their podcasts, which are about the books they read in their book groups... They told me they had to complete a graphic organizer and answer 5-6 questions in their podcast to bring to life a character from their book. Jeremy noted after class that students are... [using] voices like those of the characters and creat[ing] an atmosphere like that of their book using sound effects. (Field Notes, January 24, 2018)

Through his integration of technology, Jeremy works toward ensuring equal access for his students as part of his CRP, noting that this is part of his attempt to address the digital divide between those who have access to devices and opportunities to use applications like GarageBand at home and those who do not. "If I don't use technology, if I don't have electronic sources available, they can't [be] successful" (Interview, February 26, 2018).

Marla noted the importance of culturally diverse materials as part of her CRP in her classroom.

Making sure that they see themselves reflected in the curriculum and making sure they can see outside to the things that aren't their perspective too...the books I used [for a text features scavenger hunt] were all First Nations' content. Just like, things like that to normalize that that's part of the curriculum." (Interview, October 30, 2017)

Marla planned a multimodal inquiry unit for her Grade 5/6 class in which they explored a specific aspect of one of four cultural groups: Mi'kmaw, African Nova Scotians, Gaels, or Acadians. Before the unit began, Marla created a website with a selection of resources for her students. As she explained:

I had made a website through Google sites, so I did a fair bit of the work for them. Just because it's hard to, the resources aren't there, so it's hard to find stuff that is pertinent to what they're looking for. (Interview, February 12, 2018)

Marla invested effort in creating a website for students to access relevant information while also having some choice in their inquiry topic. She knew that because the focus of this unit was on marginalized groups in Nova Scotia, it could be difficult for students to find information without some scaffolding. As students navigated Marla's website, they honed critical literacy skills, such as selecting pertinent texts or sections of texts from within the range of options provided, while locating information about their topic. After using graphic organizers to record information about their inquiry topics, students created posters about what they had learned. Marla's goals for this activity included having students consider the 
material they gathered using critical literacy skills, and examine them from new perspectives and multiple viewpoints (Lewison et al., 2002).

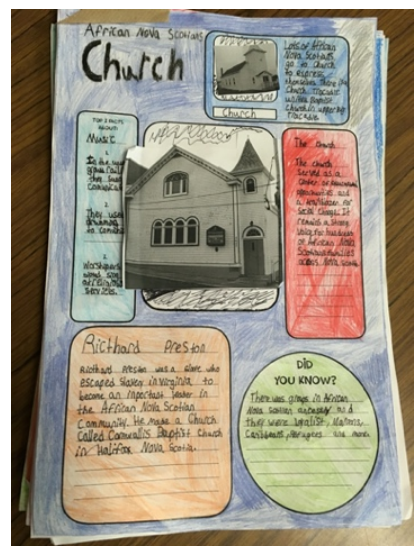

Fig. 1: African Nova Scotian Church poster, by student in Marla's classroom Feb. 12, 2018

So not just...I guess talking about...so if it was the church for example, the African Nova Scotian church, not just talking about the church, but taking different parts of the information and tying that in and seeing how...it all kind of works together. (Interview, February 12, 2018)

Marla noted she aimed to have students tie together the information they gleaned from the resources on the website and in doing so to "see how it all works together." In the poster in Figure 1, the student wrote, "The church served as a center of educational opportunities and a trailblazer for social change. It remains a strong voice of African Nova Scotian families across Nova Scotia." This statement suggests that the student who wrote it was indeed seeing the bigger picture of the importance of the church in African Nova Scotian culture, as a space for working toward social change.

\section{Discussion}

Lee (2011) explained critical literacy as "uncovering...biases [embedded in texts] that are situated in a sociopolitical context" (p. 97) with the goal of problematizing the text, a definition well aligned with CRP's focus on sociopolitical consciousness. Lopez (2011) noted that understanding "the theoretical underpinnings of [CRP is insufficient]...teachers must be able to answer for themselves the questions of what does this look like and feel like in my classroom?" (p. 76). In this section, we consider how the critical literacy practices of the teachers in our study, described in the previous section, reflect their thinking about knowledge and knowledge construction (Ladson-Billings, 1995) as one key aspect of their CRP. We use Lewison et al.'s (2002) four elements of critical literacy as a framework. 


\section{Seeing Common Events or Ideas from New Perspectives and Examining Multiple and Contradictory Viewpoints}

Jeremy's and Marla's careful planning included the selection of resources that provide students with nondominant perspectives on topics. Jeremy's intentional use of primary source documents that highlight racist immigration policies for Chinese Canadians, served to enable students to view the dominant view of Canada as a welcoming multicultural country from a new vantage point, and to question this concept. Marla's development of a website for the inquiry unit in her classroom with links to stories of successes and accomplishments of Mi'kmaw, African Nova Scotians, Gaels, and Acadians, groups that typically face and continue to face marginalization and often racism in Nova Scotia, supported her students in

gaining new perspectives on the many achievements of these groups as well as aspects of the unique cultures of each group. Jackie purposefully engaged students in reading against the grain (Borsheim et al., 2014) as a way to interrogate statements in the social studies textbook that portrayed women in subservient roles in the Middle Ages and articulate the importance of gender equity in today's society.

Each of these practices reflects a sociocultural consciousness (Ladson-Billings, 1995) through these teachers' commitment to supporting students to gain greater awareness of multiple perspectives, and to question dominant social narratives, with a goal of disrupting the commonplace (Lewison et al., 2002). Through their actions, these teachers "problematiz[ed]...existing knowledge as a historical product" (p. 383) and took a stance as teachers who refused to be cast in the traditional role of teacher as transmitter of knowledge.

We observed teachers in this study incorporating a multimodal approach both to selection of resources and to options for students to represent their learning. Marla's invitation to students to create posters to share their learning through their inquiry unit on Mi'kmaw, African Nova Scotians, Gaels, and Acadians, as well as Jeremy's use of Google classrooms and a variety of digital tools, provided students with choices that moved away from traditional textbook reading and paper-and-pencil tasks. Lopez (2011) found critical literacy gave "practical expression" (p. 78) to CRP and urged a movement away from canonical texts. The choices Marla and Jeremy made in selecting multimodal texts that give voice to marginalized voices, and in having students represent their learning digitally and through artful assignments like posters, point to their sense of knowledge construction as "counter storytelling" (Brown-Jeffy \& Cooper, 2011, p. 70).

\section{Working to Understand Sociopolitical Systems That Underpin Existing Structures and Activism for Social Change}

Lewison et al. (2002) noted that using literacy to engage in the politics of daily life is integral to bringing a critical literacy perspective to one's teaching. Ladson-Billings (1995) used the term "sociopolitical or critical consciousness" (p. 483) to describe one of three criteria she articulated as central to culturally relevant teaching. Gina's engagement of her students in the local municipal election in their area gave them a way to begin to understand the sociopolitical systems of their community and to learn how to have a voice in those systems. Marla's commitment to having all her students take part in community 
events, such as the launch of African Heritage Month, encouraged them to become involved and to see themselves as engaged and active members of the community. Lewison et al., following Giroux (1993), call for a "redefining of literacy as a form of cultural citizenship and politics that increases opportunities for... [marginalized] groups to participate in society and as an ongoing act of consciousness and resistance" (p. 383). These critical literacy practices in Gina's and Marla's classrooms offer students practical possibilities for participation in society, and affirm their right to have a voice in elections and public events, their right to take up roles as engaged citizens. They also make visible how critical literacy is eminently integral to CRP, and how critical literacy can be implemented consistently in everyday practices as a way to counter the tokenistic "celebrations" approach to CRP that Sleeter (2012) decries.

\section{Conclusion}

We have described the ways teachers who participated in this study used a critical literacy approach as part of their CRP as multimodal and intentional, moving beyond the classroom into the wider community. Teachers' views on knowledge and knowledge construction appear to reflect a sociocultural consciousness (Ladson-Billings, 1995), as they noted purposeful planning and teaching to "disrupt the commonplace... [and] "interrogat[e]...multiple viewpoints" (Lewison et al., 2002, pp. 382-383). In the cases of Gina and Marla, they also expressed a "sociopolitical or critical consciousness" (Ladson-Billings, 1995, p. 483), having students critically engage with events in their small town with the goal of supporting them to take on roles as active citizens who have voices in the affairs of their community. While these experienced teachers provided strong examples of using critical literacy instruction as part of their CRP, not all teachers are successful in this practice. Further professional learning opportunities are needed in teacher education "to counter the racism that is embedded in schools" (Hyland, 2005, p. 458) and to support more teachers to incorporate critical literacy into their CRP.

\section{References}

Alim, H. S., Baglieri, S., Ladson-Billings, G., Paris, D., Rose, D. H., \& Valente, J. M. (2017). Responding to "Cross-pollinating culturally sustaining pedagogy and universal design for learning: Toward an inclusive pedagogy that accounts for dis/ability." Harvard Educational Review, 87(1), 4-25.

Alim, H. S., Paris, D., \& Wong, C.P. (2020). Culturally sustaining pedagogy: A critical framework for centering communities. In N.S Nasir, C.D. Lee, \& R. Pea (Eds.), Handbook of the cultural foundations of learning (pp. 261-276). Routledge.

Borsheim-Black, C., Macaluso, M., \& Petrone, R. (2014). Critical literature pedagogy: Teaching canonical literature for critical literacy. Journal of Adolescent \& Adult Literacy, 58(2), 123-133.

Brown-Jeffy, S., \& Cooper, J.E. (2011). Toward a conceptual framework of culturally relevant pedagogy: An overview of the conceptual and theoretical literature. Teacher Education Quarterly, 65-84.

Creswell, J. W. (2007). Qualitative inquiry and research design: Choosing among five approaches ( $2^{\text {nd }} e d$.). Sage. 
Dover, A.G. (2009). Teaching for social justice and K-12 student outcomes: A conceptual framework and research review. Equity \& Excellence in Education, 42(4), 506-524.

Flores, M. T. (2007). Navigating contradictory communities of practice in learning to teach for social justice. Anthropology \& Education Quarterly, 38, 380-402.

Gay, G. (2002). Preparing for culturally responsive teaching. Journal of Teacher Education, 53(2), 106-116.

Giroux, H. (1993). Literacy and the politics of difference. In C. Lankshear \& P. L. McLaren (Eds.), Critical literacy: Politics, praxis, and the postmodern (pp. 367-378). State University of New York Press.

Hyland, N. E. (2005). Being a good teacher of Black students? White teachers and unintentional racism. Curriculum Inquiry, 35(4), 429-459.

Ladson-Billings, G. (1992). Culturally relevant teaching: The key to making multicultural education work. In C. A. Grant (Ed.), Research in multicultural education: From the margins to the mainstream (pp. 102-118). The Falmer Press.

Ladson-Billings, G. (1995). Toward a theory of culturally relevant pedagogy. American Education Research Journal, 32(3), 465-491. https://doi.org/10.3102/00028312032003465

Ladson-Billings, G. (2008). "Yes, but how do we do it?: Practicing culturally relevant pedagogy. In W. Ayers, G. Ladson-Billings, G. Michie, \& P. A. Noguera (Eds.), City kids, city schools: More reports from the front row (pp. 162-177). The New Press.

Ladson-Billings, G. (2014). Culturally relevant pedagogy 2.0: a.k.a. the remix. Harvard Educational Review, 84(1), 74-84.

Larson, J., \& Marsh, J. (2005) Making literacy real: Theories and practices for learning and teaching. Sage.

Lee, C. (2011). Myths about critical literacy: What teachers need to unlearn. Journal of Language and Literacy Education, 7(1), 95-102.

Lewison, M., Seely Flint, A., \& Van Sluys, K. (2002). Taking on critical literacy: The journey of newcomers and novices. Language Arts, 79(5), 382-392.

Lopez, A. E. (2011). Culturally relevant pedagogy and critical literacy in diverse English classrooms: A case study of a secondary English teacher's activism and agency. English Teaching: Practice and Critique, 10(4), 75-93.

Merriam, S. B., \& Tisdell, E. J. (2016). Qualitative research: A guide to design and implementation (4th ed.). Jossey-Bass.

Morrison, K.A., Robbins, H. H., \& Rose, D. G. (2008). Operationalizing culturally relevant pedagogy: A synthesis of classroom-based research. Equity \& Excellence in Education, 41(4), 433-454.

Norris, K, Lucas, L., \& Prudhoe, C. (2012). Examining critical literacy: Preparing preservice teachers to use critical literacy in the early childhood classroom. Multicultural Education, 19(2), 59-62.

Sleeter, C. E. (2012). Confronting the marginalization of culturally responsive pedagogy. Urban Education, 47(3), 562-584. https://doi.org/10.1177/0042085911431472 
Souto-Manning, M. (2009). Negotiating culturally responsive pedagogy through multicultural children's literature: Towards critical democratic literacy practices in a first grade classroom. Journal of Early Childhood Literacy, 9(1), 50-74. https://doi.org/10.1177/1468798408101105

Vasquez, V.M., Janks, H., \& Comber, B. (2019). Critical literacy as a way of being and doing. Language Arts, 96(5), 300-311.

Villegas, A. M., \& Lucas, T. (2002). Preparing culturally responsive teachers: Rethinking the curriculum. Journal of Teacher Education, 53(1), 20-32.

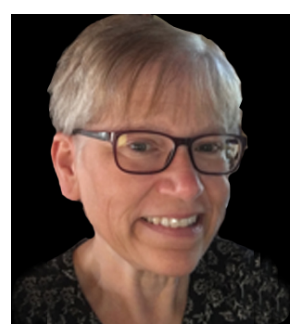

Anne Murray-Orr is a Professor of elementary education and literacy in the Faculty of Education at St. Francis Xavier University in Nova Scotia. She taught in early elementary classrooms in Saskatchewan and Nova Scotia before her university career. Her recent research interests include preservice teachers' multiliterate identities and literacy practices, early elementary graduate teacher education, and learning opportunities during the pandemic.

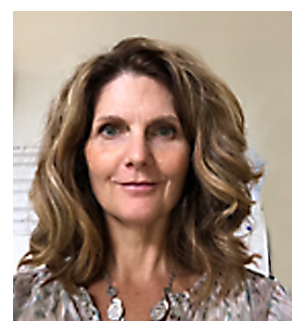

Jennifer Mitton is an Associate Professor of assessment, literacy, and qualitative research methods in the Faculty of Education at St. Francis Xavier University in Nova Scotia. Prior to university teaching, she taught in secondary schools in New Brunswick, Nova Scotia, and Turkey. Her research interests include adolescent literacies, classroom assessment, preservice teachers and LGBTQ education, and teachers as researchers. In addition to her scholarship, Dr. Mitton works closely with Nova Scotian teachers as part of professional outreach initiatives and presently serves as the Chair of the Nova Scotia Inter-University Doctoral Studies in Educational Studies Administrative Committee. 